\title{
EFFECT OF TEMPERATURE, TIME AND FASCICLE SIZE ON THE CAFFEINE CONTRACTURE TEST
}

\author{
Beverley A. Britt, Laszlo Endrenyi, Elizabeth Scott and Wanda Frodis
}

AbStract

The caffeine contracture test is the most commonly used method of diagnosing malignant hyperthermia. We have examined some factors which may influence the results of this test. These have included the temperature of the bathing solution, the size of the muscle fascicles, and the combined effect of the passage of time and prior equilibration with caffeine or with caffeine plus halothane.

For both malignant hyperthermic susceptible (MHS) and normal fascicles, caffeine contractures were greater at $37^{\circ} \mathrm{C}$ than at $22^{\circ} \mathrm{C}$, while halothane and caffeine plus halothane contractures were similar at $37^{\circ} \mathrm{C}$ and at $22^{\circ} \mathrm{C}$. Good differentiation between the normal and the MHS fascicles were observed at both temperatures although the discrimination was slightly, although not always significantly, better at $22^{\circ} \mathrm{C}$.

The weight, length or diameter of the fascicles had little or no effect on the height of the caffeine or the caffeine plus halothane contractures.

We compared caffeine plus halothane contractures exhibited by newly prepared muscle fascicles with caffeine plus halothane contractures manifested by fascicles which had already been equilibrated with cither caffeine alone or with caffeine and halothane for at least one hour. Differences in contracture heights among the techniques were small and often not significant, particularly at $37^{\circ} \mathrm{C}$. The greatest discrimination between the MHS and the normal muscle fascicles was provided by determining the caffeine plus halothane contracture curves at $22^{\circ} \mathrm{C}$, using muscle fascicles which had previously been equilibrated with incremental doses of caffeine in the absence of halothane. Slightly less accurate but still reasonably satisfactory results were also obtained at $37^{\circ} \mathrm{C}$ using muscle strips which were either freshly prepared or which had prior exposure to caffeine or to caffeine in combination with halothane and, at $22^{\circ} \mathrm{C}$, using either newly prepared muscle or muscle which had already been equilibrated with cafficine plus halothane.

The widest differentiation between the MHS and the normal muscle was given by the caffeine plus hatothane contractures and the least by the halothane contractures. MHS patients whose muscle fascicles exhibited greater than normal caffeine plus halothane contractures but normal caffeine contractures and normal halothane contractures had had the most mild clinical reactions. On the other hand MHS patients whose muscle fascicles demonstrated halothane contractures, caffeine contractures and caffeine plus halothane contractures which were all greater than normal had had the most severe reactions.

It is concluded, therefore, that if the amount of muscle available is very small, a satisfactory caffeine contracture test can still be performed by doing the various parts of the test sequentially on the same fascicle. If the time available for performing the test is limited, then the several parts of the test should rather be performed simultaneously on separate muscle fascicles.

IN RECENT YEARS the "caffeine contracture test" has frequently been used in the diagnosis of malignant hyperthermia (MH). ${ }^{1-23}$ Discussions by investigators active in $\mathrm{MH}$ research attending

Beverley A. Britt, M.D., F.R.C.P.(C), Associate Professor, Department of Anaesthesia, University of Toronto; Associate Professor, Department of Pharmacology, University of Toronto; Senior Staff Anaesthetist, Toronto General Hospital, Toronto, Ontanio, Canada. Laszlo Endrenyi, Ph.D., Professor, Department of Pharmacology, University of Toronto; Associate Professor, Department of Preventive Medicine and Biostatistics, University of Toronto, Toronto, Ontario, Canada. Elizabeth Scott, M.Sc., Laboratory Technician, Department of Anaesthesia. Wanda Frodis, B.A., Laboratory Technician, Department of Anaesthesia. the Second International Symposium on Malignant Hyperthermia in Denver in April 1977 and a workshop on MH in Galveston in March 1978 demonstrated a lack of uniformity in the performance of this test and uncertainty as to which combination of experimental methods gave the most reliable diagnosis of the $\mathrm{MH}$ trait. ${ }^{22} \mathrm{~A}$ few of the points of difference among the various laboratories included the temperature of the solution bathing the skeletal muscle fascicles $\left(22^{\circ} \mathrm{C}\right.$ vs $37^{\circ} \mathrm{C}$ ), the size of the muscle fascicles ( 100 to $500 \mathrm{mg}$ and 0.5 to $4.0 \mathrm{~cm}$ long), sequential performance of each dose-response curve on the same muscle fascicle versus parallel determination of the dose-response curves on separate 
muscle fascicles, and separate versus combined additions of caffeine and halothane to the solutions bathing the muscle fascicles. ${ }^{1-23}$

Thus $37^{\circ} \mathrm{C}$ may be more akin to normal conditions in intact human muscle than is $22^{\circ} \mathrm{C}$, but $22^{\circ} \mathrm{C}$ slows metabolism sufficiently to keep the muscle responsive to electrical and chemical stimulation for longer than at $37^{\circ} \mathrm{C}$ and a greater time is therefore available at $22^{\circ} \mathrm{C}$ to achieve reproducible dose-response curves. Furthermore, measurement at $22^{\circ} \mathrm{C}$ requires considerably less laboratory equipment than measurement at $37^{\circ} \mathrm{C}$, since the need for heating the solutions bathing the muscle fascicles is obviated.

The larger the muscle fascicle the easier is its preparation and mounting but the greater is the danger of hypoxia, acidosis and electrolyte derangement of the muscle cells deep within the interior of the fascicle. The danger of permanent functional damage to the patient's muscle belly remaining in situ is also greater. On the other hand, the smaller the muscle fascicle the greater is the probability of mechanical damage to the individual muscle cells during dissection and mounting of the fascicle. The use of small samples, however, enables biopsy material to be excised from correspondingly smaller and younger patients.

The volume of muscle required may be further reduced by obtaining sequential dose-response curves for the caffeine and then the caffeine plus halothane contractures on the same muscle fascicle, rather than simultaneously on separate muscle fascicles. Sequential determination of the dose-response curves has the additional advantage of eliminating error due to variation between fascicles. On the other hand, sequential measurement of the dose-response curves is associated, during the second part of the test, with error due to the fatiguing influence of time and the deleterious action on the muscle of the previous caffeine additions.

Contractures induced by incremental concentrations of caffeine in the absence of halothane, by halothane alone and by graded concentrations of caffeine in the presence of halothane, have all been employed in the diagnosis of the $\mathrm{MH}$ trait. It is still uncertain which of these two test drugs, either alone or in combination, provides the most reliable indication of in vivo susceptibility to $\mathrm{MH}$ reactions. It may even be that the excessive contracture responses of the MHS muscle to caffeine and to halothane are under separate genetic control. If this is so, then determination of the response (increase in resting tension or con- tracture) to both caffeine and to halothane of every muscle specimen would be necessary to fully elucidate the genetic nature of the $\mathrm{MH}$ defect in each patient.

In this study we have assessed the influence of temperature of the bathing solution, the combined effects of time and previous drug equilibration, and the size of the muscle fascicles, on isometric contractures of normal and MHS skeletal muscle fascicles. We have also investigated which test drug (caffeine alone or halothane alone) or combination of test drugs (caffeine plus halothane) provides the most accurate diagnosis of the $\mathrm{MH}$ trait.

Permission for this study was obtained from the Human Experimentation Committee of the University of Toronto. Each patient gave his or her written and verbal informed consent for the surgical procedure.

\section{METHODS}

\section{Patient classification}

Control patients were persons who had not previously had any $\mathrm{MH}$ reactions during anaesthesia and who gave a history of entirely normal anaesthetics in all of their relatives.

Malignant hyperthermia susceptible (MHS) patients were persons who had previously had MH reactions during anaesthesia characterized by muscle rigidity, fever, metabolic acidosis and tachycardia.

\section{Patient anaesthesia}

The patients were premedicated with pantopon (Omnopon) $0.25 \mathrm{mg}$ per $\mathrm{kg}$ and diazepam $0.25 \mathrm{mg}$ per kg of body weight. Anaesthesia was induced with Innovar ${ }^{\text {sp }} 0.05 \mathrm{ml}$ per $\mathrm{kg}$ of body weight and a sleep dose of diazepam. Anaesthesia was maintained with nitrous oxide, oxygen and fentanyl. We found no interference by the above agents with our in vitro studies. All patients were intubated and artificially ventilated with an Air Shields ventilator. A vapour-free gas machine was employed. Monitoring included blood pressure, electrocardiogram, heart rate and axillary and rectal temperatures. All patients were placed on a cooling blanket before induction. Ice and emergency drugs were available in the operating theatre.

\section{Patient surgical technique}

A vertical incision six centimetres in length was made over the middle portion of the vastus lateralis muscle. Without employing cautery or 
TABLE I

Human Krebs Ringer Solution

$118.1 \mathrm{mM} \mathrm{NaCl}$
$3.4 \mathrm{mM} \mathrm{KCl}$
$0.8 \mathrm{mM} \mathrm{MgSO}_{4}$
$1.2 \mathrm{mM} \mathrm{KH}_{2} \mathrm{PO}_{4}$
$11.1 \mathrm{mM} \mathrm{Glucose}$
$25.0 \mathrm{mM} \mathrm{NaHCO}_{3}$
$2.5 \mathrm{mM} \mathrm{CaCl}_{2}$
pH of medium adjusted to 7.4 at $25^{\circ} \mathrm{C}$

excessive mechanical compression, all possible fascia, fat or areolar tissue were removed from the surface of the muscle bundles before severing their blood supply. For each patient two muscle specimens were secured at each end with $5^{\circ}$ black silk sutures and then were meticulously dissected free from the surrounding vastus lateralis muscle belly while maintaining constant tension on the sutures in such a manner as to preserve the muscle cells free from contractures or from excessive stretching. The long cuts on either side of each fascicle extending between the suturcs were parallel to the long sides of the muscle cells. Thus whole and not transected muscle cells were obtained. The weight of each specimen was about 2.0 to $5.0 \mathrm{~g}$ and the length of each specimen was between 2.0 and $5.0 \mathrm{~cm}$.

Transportation of muscle specimens and preparation of muscle fascicles

Immediately after excision the two muscle specimens were transported to the laboratory, each in a separate thermos of Krebs Ringer solution at $\mathrm{pH} 7.4$ (Table I). One thermos was maintained at $22^{\circ} \mathrm{C}$ and the other at $37^{\circ} \mathrm{C}$. The time elapsed between excision and further processing in the laboratory was between 15 and 30 minutes. The specimens were trimmed free of any irregularities and remaining fat. Each was divided into four to eight pieces to permit multiple measurements. The size of each subdivided muscle fascicle was approximately 0.5 to $2.0 \mathrm{~cm}$ long, 3.0 to $8.0 \mathrm{~mm}$ in diameter and 100 to $500 \mathrm{mg}$ in weight.

\section{Equilibration of muscle fascicles}

The muscle fascicles were secured by $5^{\circ}$ black silk sutures to the lower end of plastic electrode frames (Figure 1). The fascicles on their frames were immersed in $30.0 \mathrm{ml}$ of Krebs Ringer solutions at $\mathrm{pH} 7.4$ (Table I). The upper end of each fascicle was connected by a second and much longer black silk suture to a Grass force displacement transducer (FT-03-C). The initial tension was set at $1.0 \mathrm{~g}$. In order to assess viability,

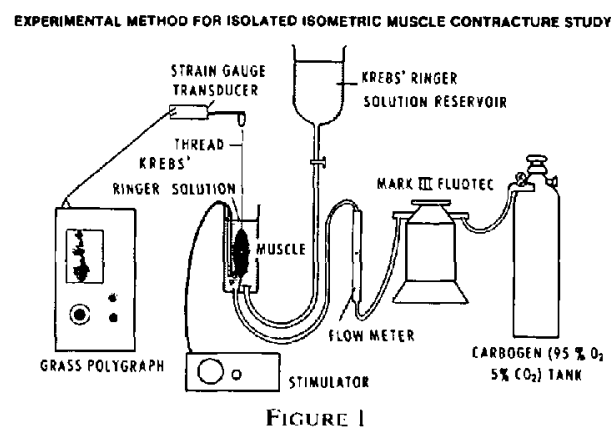

the fascicles were intermittently stimulated through platinum electrodes jutting out from the plastic frame so as to touch the mid portion of the muscle strip. The electrodes were activated by a square-wave Grass stimulator which was set to deliver 8 volt 20 millisecond impulses once every five seconds. Isometric resting tensions and twitch tensions were recorded on a Grass Model? polygraph. Oxygen containing 5.0 per cent carbon dioxide (carbogen) was bubbled through the bath at $20 \mathrm{ml}$ per minute. Equilibrations with graded doses of caffeine in the absence of halothane, and with graded doses of caffeine preceded and accompanied by 1.0 volume per cent of halothane were performed as follows:

(a) First half of test (fresh muscle):

Two fascicles - equilibrated with graded doses of caffeine ( $1 \mathrm{~A}$ and $1 \mathrm{~B})(1.0-32.0 \mathrm{mM})$ at $22^{\circ} \mathrm{C}$;

Two fascicles - equilibrated for 30 minutes with 1.0 volume per cent ( $2 \mathrm{~A}$ and $2 \mathrm{~B}$ ) halothane alone and then with 1.0 volume per cent halothane plus graded doses of caffeine $(0.25-8.0$ $\mathrm{mM}$ ) at $22^{\circ} \mathrm{C}$;

Two fascicles - equilibrated with graded doses of caffeine ( $3 \mathrm{~A}$ and $3 \mathrm{~B})(1.0-32 . \mathrm{mM})$ at $37^{\circ} \mathrm{C}$;

Two fascicles - equilibrated for 30 minutes with 1.0 volume per cent $(4 A$ and $4 B$ ) halothane alone and then with 1.0 volume per cent halothane plus graded doses of caffeine (0.25-8.0 $\mathrm{mM})$ at $37^{\circ} \mathrm{C}$.

After completing the first half of the test, the caffeine and halothane were removed by repeated washings with Krebs Ringer solution.

(b) Second half of test (commenced on the above muscle fascicles approximately one hour after the start of the first half of the test):

Four fascicles - equilibrated for 30 minutes with 1.0 volume per cent (1A, 1B, 2A, 2B) halothane alone and then with 1.0 volume per cent halothane plus graded doses of caffeine $(0.25-8.0 \mathrm{mM})$ at $22^{\circ} \mathrm{C}$; 
TABLE IIa

Effeci of Prior Equilibration of Muscle with Caffeine Plus Halothane at $22^{\circ} \mathrm{Con}$ Caffeine (Plus Halothane) Specific Concentrations

\begin{tabular}{|c|c|c|c|c|c|c|}
\hline \multirow[b]{2}{*}{$\begin{array}{l}\text { Previous drug } \\
\text { Equilibration } \\
\text { of muscle }\end{array}$} & \multicolumn{3}{|c|}{$\begin{array}{l}\text { Caffeine specific concentrations: } \\
\text { in the presence of } 1 \text { volume \% halothane }\end{array}$} & \multicolumn{3}{|c|}{ t-tests } \\
\hline & None & $\underset{\text { Caffeine }}{\text { II }}$ & $\begin{array}{l}\text { III } \\
\text { Caffeine } \\
\text { plus } \\
\text { halothane }\end{array}$ & I vs. II & I vs. III & II vs. III \\
\hline $\begin{array}{l}\text { MHS patients } \\
\quad(N=32)\end{array}$ & $\begin{array}{l}0.368^{\mathrm{b}} \\
(0.059)\end{array}$ & $\begin{array}{r}0.448^{\prime} \\
(0.071)\end{array}$ & $\begin{array}{r}0.562^{1)} \\
(0.082)\end{array}$ & $1.21 \mathrm{n.s.}$ & $2.60^{*}$ & $1.39 \mathrm{n.s}$. \\
\hline $\begin{array}{l}\text { Control patients } \\
(\mathrm{N}=20)\end{array}$ & $\begin{array}{l}1.55 \\
(0.24)\end{array}$ & $\begin{array}{c}2.66 \\
(0.49)\end{array}$ & $\begin{array}{c}2.48 \\
(0.46)\end{array}$ & $3.32 \dagger$ & $2.91 \dagger$ & $0.41 \mathrm{n} . \mathrm{s}$. \\
\hline Control/MHS & $\begin{array}{c}4.21 \\
(0.15)\end{array}$ & $\begin{array}{c}5.94 \\
(0.23)\end{array}$ & $\begin{array}{c}4.41 \\
(0.24)\end{array}$ & & & \\
\hline $\begin{array}{l}\text { t-test: } \\
\text { MHS vs. Control }\end{array}$ & $8.11 \div$ & $10.05 \ddagger$ & $8.39 t$ & $1.38 \mathrm{n.s}$. & $0.20 \mathrm{n.s}$. & 1.17 n.s. \\
\hline
\end{tabular}

"Dose of caffeine required to raise muscle tension by $1.0 \mathrm{~g}$.

"Geometric mean with its standard error in brackets.

n.s. Not significant, $P \geqq 0.05$.

$* \mathrm{P}<0.05$.

$+P<0.01$.

$\$ P<0.001$.

$\mathrm{N}=$ number of patients.

Four fascicles - equilibrated for 30 minutes with 1.0 volume per cent halothane alone and then with 1.0 volume per cent halothane plus graded doses af caffeine $(0.25-8.0 \mathrm{mM})$ at $37^{\circ} \mathrm{C}$.

Within each half of the test, each incremental drug addition was removed after five minutes equilibration but was not washed out with drugfree Krebs Ringer solution. Thus within each half of the study, the caffeine additions were cumulative. Since repeated drug-free Krebs Ringer washings were used between the first and second halves of the test, no residual caffeine would be expected to remain from the first part of the study during the second half of the test.

\section{Determination of fascicle sizes}

At the completion of the experiment each fascicle was weighed on a Model HIOT Mettler electronic balance. The length and diameter of each fascicle was measured with a micrometer screw gauge.

\section{Calculation and statistical anatysis}

The contracture amplitudes (increases in resting tensions) were measured four minutes after each drug addition. The grams tension versus log caffeine dose curves and the grams tension versus $\log$ caffeine plus 1.0 volume per cent halothane curves were plotted in duplicate at each temperature $\left(22^{\circ}\right.$ and $\left.37^{\circ} \mathrm{C}\right)$. From these data the doses of caffeine required to raise the resting muscle tensions by $1.0 \mathrm{~g}$ were determined. These concentrations were designated the "caffeine specific concentrations".

The maximum amplitudes of the contractures produced by 1.0 volume per cent halothane alone (prior to the addition of incremental caffeine doses) were measured.

The caffeine specific concentrations were evaluated by an analysis of variance of the logarithmically transformed observations. This transformation was chosen in order to secure homogeneity of the group variances. The estimated error variance was used for assessing the statistical significance of the designated contents. The results were expressed in the form of Student's t-values.

For muscle contractures, comparisons based on nonparametric tests were executed. The sign test was applied for contrasts involving paired measurements whereas the Mann-Whitney procedure tested unpaired comparisons. Probability levels for reaching conclusions are presented. The proportions of subjects having non-zero responses under various conditions were compared by simple contingency table analyses. The results were expressed as Z-values for the equivalent normally distributed variables (square roots of 
TABLE IIb

Effict of Prior Equilibration of Muscle: With Caffi:int Plus Halothanlat $37^{\circ} \mathrm{C}$ on CafFetne (Plus Halothane) Specific Concrintations

\begin{tabular}{|c|c|c|c|c|c|c|}
\hline \multirow[b]{2}{*}{$\begin{array}{l}\text { Previous drug } \\
\text { equilibration } \\
\text { of muscle }\end{array}$} & \multicolumn{3}{|c|}{$\begin{array}{l}\text { Caffeine specific concentrations } \\
\text { in the presence of } 1 \text { volume } \% \text { halothane }\end{array}$} & \multicolumn{3}{|c|}{ t-tests } \\
\hline & $\begin{array}{c}1 \\
\text { None }\end{array}$ & $\stackrel{\text { Il }}{\text { Caffeine }}$ & $\begin{array}{c}\text { Ill } \\
\text { Caffeine } \\
\text { plus } \\
\text { halothane }\end{array}$ & I vs. II & I vs. III & II vs. III \\
\hline $\begin{array}{l}\text { MHS patients } \\
\quad(\mathrm{N}=32)\end{array}$ & $\begin{array}{r}0.518^{h} \\
(0.080)\end{array}$ & $\begin{array}{r}0.728^{b} \\
(0.127)\end{array}$ & $\begin{array}{r}0.704^{\mathrm{b}} \\
(0.094)\end{array}$ & $2.10^{*}$ & $1.89 \mathrm{n.s}$ & $0.21 \mathrm{n} . \mathrm{s}$. \\
\hline $\begin{array}{l}\text { Control patients } \\
\qquad(\mathrm{N}=20)\end{array}$ & $\begin{array}{c}1.65 \\
(0.32)\end{array}$ & $\begin{array}{c}2.30 \\
(0.30)\end{array}$ & $\begin{array}{c}2.31 \\
(0.31)\end{array}$ & $2.02^{*}$ & $2.05^{*}$ & 0.04 n.s. \\
\hline Control/MHS & $\begin{array}{l}3.19 \\
(0.20)\end{array}$ & $\begin{array}{c}3.16 \\
(0.28)\end{array}$ & $\begin{array}{c}3.28 \\
(0.22)\end{array}$ & & & \\
\hline $\begin{array}{l}\text { t-test: } \\
\text { MHS vs. Control }\end{array}$ & $6.56 \neq$ & $6.48 \ddagger$ & $6.71 \div$ & $0.05 \mathrm{n} . \mathrm{s}$. & 0.11 n.s. & $0.16 \mathrm{n.s}$. \\
\hline
\end{tabular}

"Dose of caffeine required to raise muscle tension by $1.0 \mathrm{~g}$

"Geonetric mean with its standard crror in brackets.

n.s. Not significant, $P \geqq 0.05$.

$* P<0.05$.

$+\mathrm{P}<0.01$.

$¥ \mathrm{P}<0.001$.

$\mathrm{N}=$ number of patients.

TABLE IIc

Interacition t-Statistics Comparing Prior Equilibration of Muscle With Cafflinl Plus halothane

\begin{tabular}{|c|c|c|c|c|c|c|}
\hline $\begin{array}{l}\text { Previous drug } \\
\text { equilibration } \\
\text { of muscle }\end{array}$ & $\underset{\text { None }}{\mathrm{I}}$ & $\underset{\text { Caffeine }}{\text { II }}$ & $\begin{array}{l}\text { III } \\
\text { Caffeine } \\
\text { plus } \\
\text { halothane }\end{array}$ & I vs. II & I vs. III & ll vs. III \\
\hline $\begin{array}{l}\text { MHS patients } \\
\quad(\mathrm{N}=32)\end{array}$ & $2.10^{*}$ & $2.99 \dagger$ & 1.39 n.s. & $0.63 \mathrm{n.s}$ & 0.50 n.s. & 1.13 n.s. \\
\hline $\begin{array}{l}\text { Control patients } \\
\qquad(\mathrm{N}=20)\end{array}$ & 0.36 n.s. & $0.77 \mathrm{n} . \mathrm{s}$ & $0.38 \mathrm{n} . \mathrm{s}$ & 0.93 n.s. & $0.61 \mathrm{n} . \mathrm{s}$. & 0.32 n.s. \\
\hline $\begin{array}{l}\text { t-test: } \\
\text { MHS vs. Control }\end{array}$ & $1.10 \mathrm{~ns}$ & $2.53 \dagger$ & 1.19 n.s. & $1.10 \mathrm{nss}$ & 0.07 n.s. & 0.94 n.s. \\
\hline
\end{tabular}

n.s. Not significant, $P \geqq 0.05$

$* P<0.05$.

$+\mathrm{P}<0.01$.

$\ddagger \mathrm{P}<0.001$.

$\mathrm{N}=$ number of patients.

the corresponding $\mathrm{X}^{2}$-statistics with one degree of freedom).

\section{RESULtS}

A. Effect of Patient Status on Caffeine Specific Concentrations, Caffeine Plus Halothane Specific Concentrations, and on HalothaneInduced Contractures

Incremental concentrations of caffeine in the presence of 1.0 volume per cent halothane produced caffeine specific concentrations that were always smaller at $22^{\circ} \mathrm{C}$, and were usually smaller at $37^{\circ} \mathrm{C}$ in the MHS than in the control fascicles (Tables Ila and IIb and IIc).

Graded doses of caffeine in the absence of halothane usually, but not always, yielded caffeine specific concentrations that were smaller in the MHS than in the control muscle strips at both $22^{\circ}$ and at $37^{\circ} \mathrm{C}$ (Table III). Thus the caffeine 
TABLE III

EfFect of Temperature on Caffeine Specific ConClentrations in the ABsence of Halothane

\begin{tabular}{lccc}
\hline \hline & $22^{\circ} \mathrm{C}$ & $37^{\circ} \mathrm{C}$ & $\begin{array}{c}\text { t-test } \\
22^{\circ} \text { vs. } 37^{\circ} \mathrm{C}\end{array}$ \\
\hline MHS paticnts & $5.22^{\mathrm{b}}$ & $2.80^{\mathrm{b}}$ & $3.84 \ddagger$ \\
$(\mathrm{N}=32)$ & $(0.65)$ & $(0.40)$ & \\
Control patients & 17.33 & 5.55 & $6.02 \ddagger$ \\
$(\mathrm{N}=20)$ & $(2.08)$ & $(0.63)$ & \\
Normal/MHS & 3.32 & 1.98 & \\
& $(1.54)$ & $(0.73)$ & \\
t-test: & $12.53 \ddagger$ & $7.17 \ddagger$ & \\
MHS vs. Control & & & \\
t-test: (MHS vs Control) as $\left(22^{\circ} \mathrm{C}\right.$ vs. $\left.37^{\circ} \mathrm{C}\right)$ & $2.05^{*}$ \\
\hline
\end{tabular}

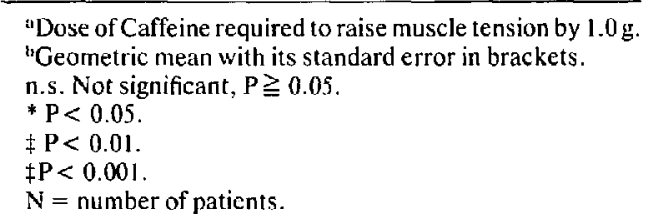

specific concentrations for 15 out of 17 MHS fascicles were smaller than those exhibited by all the control muscle fascicles.

At both $22^{\circ} \mathrm{C}$ and $37^{\circ} \mathrm{C}$ one volume per cent halothane in the absence of caffeine induced contractures in the MHS muscle fascicles which were more frequent and higher than those exhibited by the control fascicles. (Table IV). The differences in the contracture frequencies were highly significant at both temperatures. The differences in the contracture amplitudes were statistically significant at $37^{\circ} \mathrm{C}$ and nearly significant at $22^{\circ} \mathrm{C}$ when all subjects were compared. When only the subjects having non-zero responses were compared, the differences of contracture amplitude were not significant at either temperature. This was so because the number of non-zero observations in the control group was insufficient to reveal statistically significant differences. Thus at $37^{\circ} \mathrm{Conly}$ one out of 20 control muscles exhibited a very slight increase in resting tension $(0.1 \mathrm{~g})$, while 13 out of 30 MHS fascicles displayed contractures of between 1.25 and 4.2 grams with a mean of $1.16 \mathrm{~g}$. Similarly, at $22^{\circ} \mathrm{C}$ only four control muscles developed contractures ranging from 0.15 to $0.9 \mathrm{~g}$ with a mean of $0.61 \mathrm{~g}$ while 15 MHS fascicles exhibited contractures of between 0.1 and $5.5 \mathrm{~g}$ with a mean of $1.13 \mathrm{~g}$ (Table IV).

MHS patients exhibiting contractures in the presence of halothane alone tended to have had the most severe clinical reactions (as determined by maximum temperature and heart rate, in- tensity of skeletal muscle rigidity, degree of metabolic and respiratory acidosis and postoperative elevations of serum creatine kinase and urine myoglobin). The muscle fascicles of these severely affected patients also always demonstrated lower than normal caffeine specific concentrations and caffeine plus halothane specific concentrations. MHS patients whose caffeine plus halothane specific concentrations were smaller than normal but whose caffeine specific concentrations were normal and whose muscle did not exhibit contractures in the presence of halothane alone had the least severe clinical reactions. MHS patients whose muscle did not develop halothane induced contractures but whose caffeine and caffeine plus halothane concentrations were less than normal had clinical reactions that were intermediate in severity between the above two groups of patients.

B. Combined effect of time and previous drug equilibration on caffeine plus halothane specific concentrations

We compared at $22^{\circ} \mathrm{C}$ (Table IIa) and at $37^{\circ} \mathrm{C}$ (Table IIb), for MHS and for control muscle, three categories of caffeine plus halothane specific concentrations. These were obtained as follows:

I - on freshly mounted muscle fascicles that had not been previously exposed to caffeine or to caffeine plus halothane;

II - on muscle fascicles that had undergone 


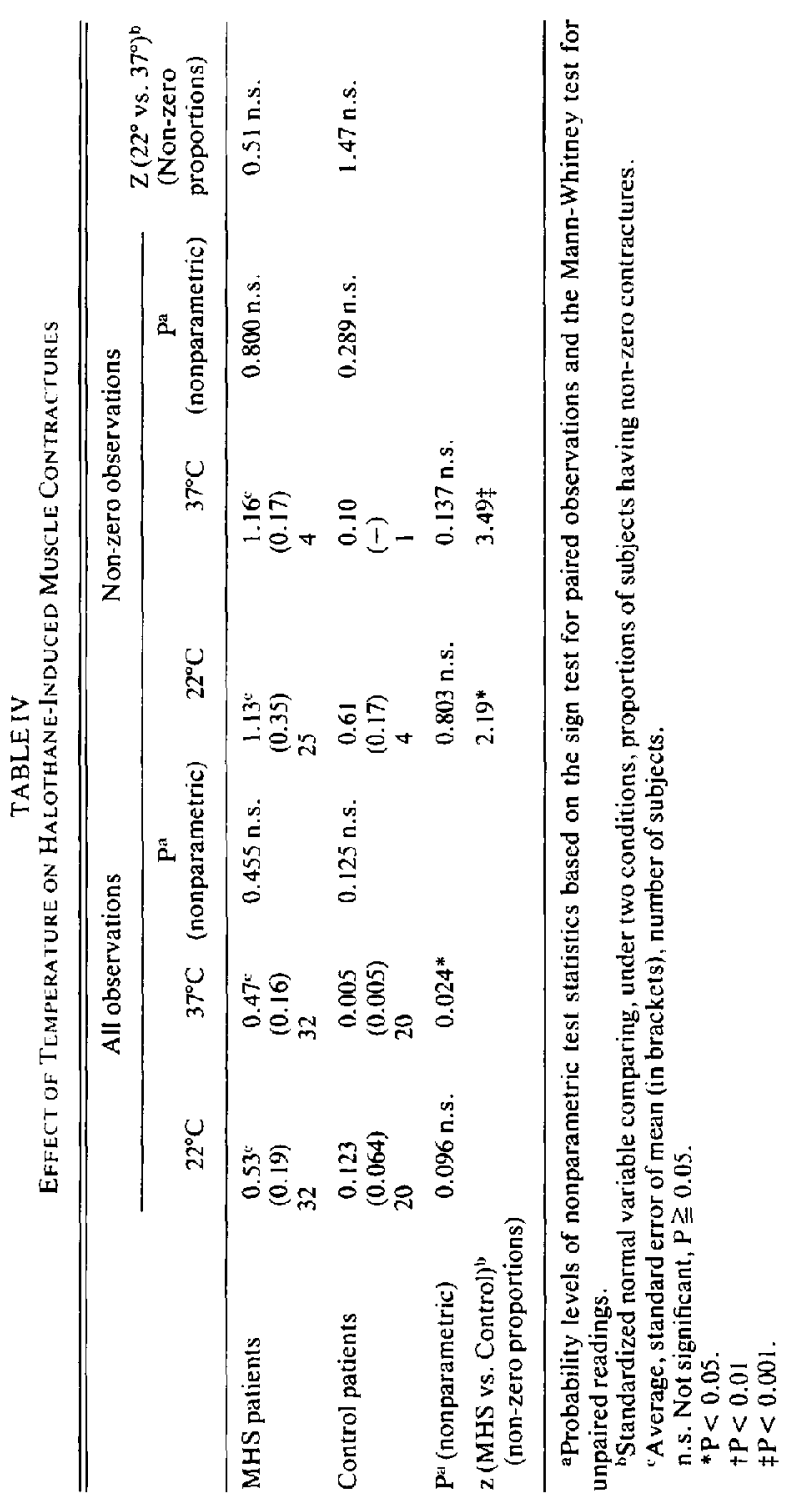


CANADIAN ANAESTHETISTS' SOCIETY JUURNAL

TABLE V

averagt. Weights and Lengths of Muscle Fascicles at $22^{\circ} \mathrm{C}$ and $37^{\circ} \mathrm{C}$ in Control and MHS Patients

\begin{tabular}{|c|c|c|c|c|c|}
\hline & & \multicolumn{2}{|c|}{ Control patients } & \multicolumn{2}{|c|}{ MHS patients } \\
\hline & & Weight & Length & Weight & Length \\
\hline $\begin{array}{c}22^{\circ} \mathrm{C} \\
\text { caffeine } \\
\text { only }\end{array}$ & $\begin{array}{l}\text { Mean } \\
\text { S.E. } \\
\text { N } \\
\text { Correl. } \\
\text { coeffic. }\end{array}$ & $\begin{array}{l}241.5 \\
26.7 \\
19 \\
-0.25 \text { n.s. }\end{array}$ & $\begin{array}{c}13.32 \\
1.07 \\
19 \\
-0.12 \text { n.s. }\end{array}$ & $\begin{array}{l}264.2 \\
20.9 \\
29 \\
-0.16 \text { n.s. }\end{array}$ & $\begin{array}{c}12.90 \\
0.56 \\
29 \\
-0.40^{*}\end{array}$ \\
\hline $\begin{array}{c}22^{\circ} \mathrm{C} \\
\text { cuffeine }+ \\
\text { halothane }\end{array}$ & $\begin{array}{l}\text { Mean } \\
\text { S.E. } \\
\text { N } \\
\text { Correl. } \\
\text { coeffic. }\end{array}$ & $\begin{array}{l}236.6 \\
34.2 \\
12 \\
0.12 \text { n.s. }\end{array}$ & $\begin{array}{c}12.42 \\
0.99 \\
12 \\
-0.06 \text { n.s. }\end{array}$ & $\begin{array}{l}304.7 \\
36.4 \\
18 \\
0.13 \text { n.s. }\end{array}$ & $\begin{array}{c}13.50 \\
0.74 \\
18 \\
0.25 \mathrm{n.s}\end{array}$ \\
\hline $\begin{array}{c}37^{\circ} \mathrm{C} \\
\text { caffeine } \\
\text { only }\end{array}$ & $\begin{array}{l}\text { Mean } \\
\text { S.E. } \\
\text { N } \\
\text { Correl. } \\
\text { coeffic. }\end{array}$ & $\begin{array}{l}219.9 \\
29.6 \\
18 \\
-0.37 \text { n.s. }\end{array}$ & $\begin{array}{c}13.28 \\
0.84 \\
18 \\
0.01 \text { n.s. }\end{array}$ & $\begin{array}{l}245.0 \\
22.7 \\
27 \\
-0.16 \text { n.s. }\end{array}$ & $\begin{array}{c}13.00 \\
0.71 \\
27 \\
-0.34 *\end{array}$ \\
\hline $\begin{array}{c}37^{\circ} \mathrm{C} \\
\text { caffeine }+ \\
\text { halothane }\end{array}$ & $\begin{array}{l}\text { Mean } \\
\text { S.E. } \\
N \\
\text { Correl. } \\
\text { coeffic. }\end{array}$ & $\begin{array}{c}201.5 \\
39.5 \\
11 \\
-0.01 \text { n.s. }\end{array}$ & $\begin{array}{c}11.36 \\
0.79 \\
11 \\
-0.52^{*}\end{array}$ & $\begin{array}{l}246.4 \\
29.0 \\
17 \\
-0.11 \text { n.s. }\end{array}$ & $\begin{array}{c}13.9 \\
0.95 \\
17 \\
-0.18 \text { n.s }\end{array}$ \\
\hline
\end{tabular}

$* \mathrm{P}<0.05$.

n.s. Not significant.

$\mathrm{n}_{\mathrm{s} \times \mathrm{u}}=\mathrm{n}+\mathrm{I}$.

Correl. Coeffic. $=$ correlation coefficients which characterize the relationships between the caffeine specific concentrations and either the weights or lengths of the fascicles.

prior equilibration with incremental doses of caffeine alone for at least one hour;

III - on muscle fascicles that had already been subjected to graded concentrations of caffeine in the presence of halothane for at least one hour.

At both temperatures the caffeine specific concentrations were lower without (I) than with (II or III) prior exposure to caffeine or caffeine plus halothane. Six of the eight possible comparisons were statistically significant and one additional one was nearly so (Table III). Caffeine specific concentrations observed following equilibration with caffeine were similar regardless of whether the prior exposure took place in the presence of (III) or in the absence of halothane (II) (Table Ila, IIb and IIc).

C. Effect of temperature on caffeine and caffeine plas halothane specific concentrations

In the absence of halothane the caffeine specific concentrations were lower at $37^{\circ} \mathrm{C}$ than at $22^{\circ} \mathrm{C}$ (Table III). In the presence of halothane, however, the caffeine specific concentrations of the control fascicles were similar at the two temperatures, while those of the MHS fascicles were slightly and in the case of the measurements on fresh muscles (method I) and those following caffeine exposure (method II), significantly higher than at $22^{\circ} \mathrm{C}$.

The ratios of the caffeine specific concentrations of the normal muscle strips to the caffeine specific concentrations of the MHS muscle strips were measures of the separation of the normal and the MHS dose-response curves and, therefore, of the diagnostic power of the method. The resolving power was somewhat higher at $22^{\circ} \mathrm{C}$ than at $37^{\circ} \mathrm{C}$ but the difference reached statistical significance only in the presence of halothane following prior exposure to caffeine (Tables Ila, IIb and IIc). Without halothane, however, the test was also somewhat more discriminating at the lower temperature (Table III).

D. Effect of temperature on halothane-induced contractures

At $22^{\circ} \mathrm{C}$, for MHS and for control individuals, halothane equilibration caused contractures of 
the muscle fascicles which were of slightly greater frequency than at $37^{\circ} \mathrm{C}$. The differences, however, were not significant (Table IV). Similarly at $22^{\circ} \mathrm{C}$ for both MHS and control muscle fascicles the halothane-induced contractures were not statistically different. This was true when all observations were included and when zero readings were excluded.

The differences between the control and MHS halothane induced contracture amplitudes and frequencies were greater at $37^{\circ} \mathrm{C}$ than at $22^{\circ} \mathrm{C}$ (Table IV).

E. Effect of fascicle weight, length and diameter on "caffeine and caffeine plus halothane specific concentrations"

At $22^{\circ} \mathrm{C}$ and at $37^{\circ} \mathrm{C}$ and for both control and MHS muscle, correlations between caffeine and caffeine plus halothane specific concentrations on the one hand and weight and length of the fascicles on the other hand were absent or slight (Table V).

\section{Discussion}

Comparison of the "caffeine specific concentrations" in the absence of halothane, halothane contractures in the absence of caffeine and caffeine specific concentrations in the presence of halothane have shown that useful information was usually obtained from all three procedures. The greatest and most reliable differentiation between the control and the MHS muscle fascicles, however, was provided by the "caffeine specific concentrations" in the presence of halothane. The least discrimination was given by the halothane contractures, while the caffeine specific concentrations in the absence of halothane occupy an intermediale position.

Because $\mathrm{MH}$ does not appear to be a single gene defect but to be rather governed by at least two different genes ${ }^{2.8 .13 .24}$ the number of possible phenotypes exceeds three and may theoretically comprise nine (eight abnormal and one normal). Clinically these may be very difficult to distinguish. Rather, they may present a spectrum ranging from the very severe to the almost normal. Our observations demonstrate this spectrum, not only in terms of the gradations within the contractures induced by caffeine alone, by caffeine plus halothane and by halothane alone, but also in terms of whether or not each of these three parameters were or were not normal. The most abnormal patients appear to be those MHS patients who develop halothane contractures while the least abnormal patients appear to be those who exhibit greater than normal contractures only when both halothane and caffeine are added to the bathing solution (i.e. have lower than normal caffeine plus halothane specific concentrations). To obtain the maximum amount of information regarding the severity and the genetic nature of the defect contractures induced by caffeine, halothane and halothane plus caffeine must each be separately measured.

The higher contractures which resulted from the addition of caffeine alone to the control and to the MHS muscle strips at $37^{\circ} \mathrm{C}$ than $22^{\circ} \mathrm{C}$ were probably due to the greater rate of calcium related metabolic functions within the muscle at the former temperature. For instance, calcium is taken up into the sarcoplasmic reticulum $(\mathrm{SR})$ at a more rapid rate at $37^{\circ} \mathrm{C}$ than at $22^{\circ} \mathrm{C} .{ }^{23}$ This greater active uptake of $\mathrm{Ca}^{++}$appears to be due to higher activity of SR ATPase at $37^{\circ}$ than at $22^{\circ} \mathrm{C}^{25-27}$ The greater solubility of caffeine at $37^{\circ}$ $\mathrm{C}$ than at $22^{\circ} \mathrm{C}^{28}$ may also be at least partially responsible for the larger rises in resting tensions of the muscle fascic les at the higher temperature.

The data have indicated that the combined influences of prior administration of caffeine or caffeine plus halothane, along with the concomitant passage of time (at least one hour), had a very slight ability to reduce contractures of the muscle strips. Of the three methods of measuring the response of the muscle to caffeine in the presence of halothane, method II (i.e. measurement on muscle fascicles previously equilibrated with incremental doses of caffeine in the absence of hatothane) at $22^{\circ} \mathrm{C}$ gave the greatest discrimination between the control and the MHS muscle. If therefore, only a small amount of muscle is available for testing, as for example from a small child valid information can still be obtained by performing the study sequentially on only one muscle fascicle (or if possible on two duplicate muscle fascicles), obtaining first the dose-response curve for incremental doses of caffeine alone, then measurements of contractures in the presence of 1.0 volume per cent halothane alone and finally the dose-response curve for 1.0 volume per cent halothane plus incremental doses of caffeine. Even though the contractures were slightly lower with method II than with method I (measurement of halothane plus caffeine-induced contractures on muscle previously unexposed to either of these drugs), the differences were so small that method II is considered to be accepta- 
ble not only for small paediatric patients but also for adults.

Further reductions in the size of muscle biopsies can be achieved by preparing very small fascicles. This is valid since the weights, lengths and diameters of the fascicles generally did not correlate at all, or only slightly, with the caffeine or the caffeine plus halothane specific concentrations.

If the limiting factor is not the volume of muscle available for study but rather time available in which to examine the muscle (as for instance during a surgical and/or anaesthetic emergency) then adequate results can be obtained by obtaining the caffeine specific concentrations and the caffeine plus halothane specific concentrations simultaneously on separate muscle fascicles.

Our results are in partial but not complete agreement with those of Nelson and his coworkers. ${ }^{26}$ Thus, on examination of three control and three MHS pig muscles they found, ${ }^{25}$ as we did, that temperature had no effect on contractures induced by halothane plus caffeine. In the presence of halothane alone they reported ${ }^{25}$ that contractures did not occur in any of the fascicles isolated from the three control pigs at either $25^{\circ} \mathrm{Cor} 37^{\circ} \mathrm{C}$. On the other hand, for the fascicles obtained from the three MHS pigs, contractures did not develop at $25^{\circ} \mathrm{C}$ but did, usually although not always, at $37^{\circ} \mathrm{C}$. This difference from our data may have been due to differences in measurement technique, the very small sample size reported by Nelson and colleagues and the different species employed by them, namely the pig. In a separate study using normal human muscle Nelson, et al. ${ }^{26}$ found that caffeine induced contractures were higher at $37^{\circ} \mathrm{C}$ than at $22^{\circ} \mathrm{C}$. For normal human muscle, therefore, we are in substantial agreement with Nelson.

\section{Conclusions}

In performing the caffeine contracture test meaningful results can be ascertained at both $22^{\circ} \mathrm{C}$ and at $37^{\circ} \mathrm{C}$, on small or large muscle fascicles and on freshly prepared muscle strips or muscle fascicles previously exposed for at least one hour to caffeine or to caffeine plus halothane. It is recommended that when only a small muscle biopsy is available it be subdivided into very small muscle fascicles and that the number of fascicles prepared be reduced by one half by performing the caffeine-contracture response curve, the halothane induced contractures and the caffeine plus halothane contracture response curve sequentially on the same muscle strip. On the other hand, during an emergency when speed of measurcment is the limiting factor, the caffeine contracture response curve and the caffeine plus halothane contracture response curve should be determined simultaneously on separate muscle fascicles.

\section{REFERENCES}

1. Kalow. W., Britt, B.A., Terreau, M.E. \& HaIsT, C. Metabolic error of muscle metabolism after recovery from malignant hyperthermia. Lancet ii: 895 (1970)

2. Kalow, W., Britt, B.A. \& Richter A. The caffeine test of isolated human muscle in relation to malignant hyperthermia. Canad. Anaesth. Soc. J. 24:678(1977)

3. Kalow, W., Britt, B.A. \& Peters, P. Rapid simplified techniques for measuring caffeine contraction for paticnts with malignant hyperthermia. In Second International Symposium on Malignant Hyperthermia, ed. J.A. Aldrete and B.A. Britt, pp. 339-350. New York: Grune \& Stratton (1978).

4. Britt, B.A., Kalow, W., Gordon. A., HumPhrey, J.G, \& RewCastle, N.B. Malignant hyperthermia - an investigation of five patients. Canad. Anaesth. Soc. J. 20: 431 (1973).

5. Britt. B.A. \& Kalow, W. Malignant hyperthermia - an investigation of three patients. Ann. Roy. Coll. Surg. 48: 73 (1971).

6. Britt, B.A., Endreny, L., Cadman, D. L., Fan, H.M. \& FUNG, H.Y-K. Porcine malignant hyperthermia: effects of halothane on mitochondrial respiration and calcium accumulation. Anesthesiology 42: 292 (1975).

7. BRITT, B.A. MCCOMAS, A.J., ENDRENy, L. \& KALOW, W. Motor unit counting and the caffeine contracture test in malignant hyperthermia. Anaesthesiology 47: 490-497 (1977).

8. BritT. B.A., Kalow, W. \& Endrenri, L. Malignant hyperthermia - pattern of inheritance in swine. In Second International Symposium on Malignant Hyperthermia, ed. J.A. Aldrete and B.A. Britt, pp. 195-211. New York: Grune \& Stratton (1978).

9. Ellis, F.R., Harriman, D.G.F., Keaney, N.P., KYEl-MeNSAH, K. \& TYRRFLL, J.H. Halothaneinduced muscle contracture as a cause of hyperpyrexia. Brit. J. Anaesth. 43: 721 (1971).

10. Ellis, F.R. \& Harriman, D.G.F. A new screening test for susceptibility to malignant hyperpyrexia. Brit. J. Anaesth. 45: 638 (1973).

11. Ellis, F.R., Clarke, I.M.C., Appleyard, T.N, \& Dinsdale, R.C.W. Malignant hyperpyrexia induced by nitrous oxide and treated with dexamethasone. Brit. Med. J. 4: 270 (1974).

12. Ellis, F.R., Harriman, D.G.F., Currie, S. \& CAIN, P.A. Screening for malignant hyperthermia in susceptible patients. In Second International Symposium on Malignant Hyperthermia, ed. J.A. Aldrete and B.A. Britt, pp. 273-285. New Yark: Grune \& Stratton (1978)

13. Ellis, F.R., Cain, P.A. \& Harriman, D.G.F. Multifactorial inheritance of malignant hyperther- 
mia susceptibility. In Second International Symposium on Malignant Hyperthermia, ed. J.A. Aldrete and B.A. Britt, pp. 329-338. New York: Grune \& Stratton (1978).

14. MircheLSON, K.R. "Investigations on Malignant Hyperpyrexia". Ph.D. dissertation, University of Melbourne (1974).

15. Muulus, R.F.W., Young, A., Jones, D.A. \& EDWARDS, R.H.T. A study of the contractility, biochemistry, and morphology of an isolated preparation of human skeletal muscle. Clin. Sci. \& Molec. Med. 52: 291 (1977).

16. Muulos, R.F.W. \& Denborough. M.A. Identification of susceptibility to malignant hyperpyrexia. Brit. Med. J. 2: 241 (1974).

17. Moulos, R.F.W. \& Denborough, M.A. Biochemical basis of malignant hyperthermia. Brit. Med, J. 2: 245 (1974).

18. Moulds, R.F.W. "Studies on Malignant Hyperthermia". Ph.D. dissertation, University of Melbourne (1974).

19. Nelson. T.E., Bedell. D.M. \& Jones, E.W. Porcine malignant hyperthermia: effects of temperature and extracellular calcium concentration on halothane-induced contracture of susceptible skeletal muscle. Anesthesiology 42: 301 (1975).

20. NELSON, T.E. Excitation-contraction coupling: a common etiologic pathway for malignant hyperthermia susceptible muscle. In Second International Symposium on Malignant Hyperthermia, ed. J.A. Aldrete and B.A. Britt, pp. 329-338. New York: Grune \& Stratton (1978)

21. Anderson, I.L.\& Jones, E.W. Porcine malignant hyperthermia: effect of dantrolene sodium on in vitro halothane-induced contraction of susceptible muscle. Anesthesiology 44: 47 (1976).

22. AldRete, J.A.\& BritT, B.A. (eds.) Second International Symposium on Malignant Hyperthermia. Grune \& Stratton (1978).

23. Workshop on malignant hyperthermia. Galveston, Texas. March 1978.

24. Williams, C.H., Shanklin, M.D., Hedrick, H.B., Huhrler. M.E., Stubas. D.H., Kraust. G.F., Payne, G.C., Benelsict, J.D., Hutche:SON, D.P. \& JoHN F. LASLEY. The fulminant hyperthermia-stress syndrome: genetic aspects, hemodynamic and metabolic measurements in susceptible and normal pigs. In Second International Symposium on Malignant Hyperthermia, ed. J.A. Aldrete and B.A. Britt, pp. 113-140. New York: Grune \& Stratton (1978)

25. Masuda, H. \& dE MeIS, L. Effect of temperature on the $\mathrm{Ca}^{2}$ and transport ATPase of sarcoplasmic reticulum. J. Biol. Chem. 252;8567 (1971).

26. Nelson, T.E., Bedell, D.M. \& Jones, E.W. Porcine malignant hyperthermia: effects of temperature and extracellular calcium concentration on halothane-induced contracture of susceptible skeletal muscle. Anesthesiology 42: 301 ( 1975 ).

27. MERCK INDEx, 8th ed. Martha Windholzed. Merck \& Co. Rahway N.J.

28. SReter, F.A. Temperature, $\mathrm{pH}$ and seasonal dependence of $\mathrm{Ca}$ - up take and ATPase activity of white and red muscle microsomes. Archives of Biochem. and Biophys. 134: 25-33 (1969).

\section{RÉSUMÉ}

Le test à la caféine est la méthode la plus courante pour établir le diagnostic d'hyperthermie maligne. Nous avons étudié certains facteurs susceptibles de modifier les résultats, à savoir la température de la solution où baigne le spécimen musculaire, le calibre des fibres musculaires, et les effets combinés de la durée d'exposition et atteinte d'équilibre avec la caféine ou la caféine associée à l'halothane.

Pour la fibre normale comme pour celle de sujets susceptibles de présenter de l'hyperthermie maligne, les contractures étaient plus importantes à $37^{\circ}$ qu'à $22^{\circ} \mathrm{C}$. Les réponses étaient semblables aux deux températures si l'halothane était utilisé. On pouvait bien différencier le muscle normal de l'anormal aux deux températures bien que la différence était légèrement plus visible (pas toujours de façon significative) à $22^{\circ}$ qu'à $37^{\circ} \mathrm{C}$.

Le poids, la longueur et le diamètre des fibres n'avaient pas ou peu d'effet sur le résultat du test.

Nous avons comparé les résultats du test à la caféine-halothane sur des fibres qui venaient d'ètre préparées avec ceux observés lorsque les fibres avaient été équilibrées par une heure d'exposition à la solution de caféine ou de caféine-halothane. Les différences étaient petites et souvent non significatives, en particulier à $37^{\circ} \mathrm{C}$. Les meilleurs conditions pour différencier la fibre normale de l'anormale se retrouvaient en établissant la réponse à la caféine-halothane à $22^{\circ} \mathrm{C}$ avec des fibres équilibrées au préalable à des doses progressives de caféine sans halothane. On obtenait des résultats légèrement moins précis mais encore acceptables à $37^{\circ} \mathrm{C}$ avec des fibres fraichement préparées ou équilibrées à la caféine-halothane.

La meilleure différenciation entre la normalité et l'anormalité était obvservée avec l'association caféine-halothane et la moins bonne avec la contracture à l'halothane. Les patients susceptibles àl'hy perthermie présentant une réponse à la caféine-halothane plus grande que la normale, mais une réponse normale à la caféine ou à l'halothane isolés, présentaient les phénomènes cliniques les plus discrets. Ceux dont les résultats étaient supérieurs à la normale avec la caféine, l'halothane et l'association caféine-halothane, présentaient les manifestations cliniques les plus graves.

Il est conclu que si la quantité de muscle disponible est petite, on peut tout de même obtenir un test valable en procédant aux différentes étapes de façon séquentielle. Si l'urgence exige des résultats rapides, il vaut mieux procéder simultanément aux différentes étapes en utilisant des fibres séparées. 